\title{
Social representations elaborated by nurses about climacteric women in primary health care
}

\author{
Representações sociais elaboradas por enfermeiras acerca da assistência à mulher \\ climatérica na atenção primária
}

Smithanny Barros da Silva ${ }^{1}$, Inez Sampaio Nery ${ }^{2}$, Ayla Maria Calixto de Carvalho ${ }^{1}$

Objective: to understand the social representations elaborated by nurses from the family health strategy concerning the assistance to climacteric women. Methods: qualitative research conducted with 28 nurses. One adopted the reference of procedural approach of the theory of social representations. The interviews were recorded and transcribed completely and processed by the Software of Lexical Analysis of co-occurrence in simple statements of a text, version 4.7. Results: nurses recognize the menopause as a phase of women's life that needs to be assisted in its entirety, however, they showed difficulty in helping them, as they just carry out the cytological examination collection, request laboratory tests and forward them to a doctor. Conclusion: the climacteric period is a multifaceted phenomenon and the assistance to those people should be systematized from a qualified listening, in an approach that respects its uniqueness and autonomy.

Descriptors: Nursing Care; Primary Health Care; Climacteric.

Objetivo: apreender as representações sociais elaboradas por enfermeiras da Estratégia Saúde da Família acerca da assistência à mulher climatérica. Métodos: pesquisa qualitativa realizada com 28 enfermeiras. Adotou-se o referencial da abordagem processual da Teoria das Representações Sociais. As entrevistas foram gravadas e transcritas na íntegra e processadas pelo Software de Análise Lexical de Coocorrências em Enunciados Simples de um Texto versão 4.7. Resultados: as enfermeiras reconhecem o climatério como uma fase da vida da mulher que precisa ser assistida na sua integralidade, no entanto, demonstraram dificuldade em assisti-la, apenas realizam a coleta do exame citológico, solicitam exames laboratoriais e encaminham ao médico. Conclusão: o climatério é um fenômeno multifacetado e a assistência a esse público deve ser sistematizada a partir de escuta qualificada, numa abordagem que respeitem a sua singularidade e autonomia.

Descritores: Assistência de Enfermagem; Atenção Primária à Saúde; Climatério.

\footnotetext{
${ }^{1}$ Fundação Municipal de Saúde. Teresina, PI, Brazil.

${ }^{2}$ Universidade Federal do Piauí. Teresina, PI, Brazil.

Corresponding author: Smithanny Barros da Silva

Rua Peru, 1627, bairro Cidade Nova. CEP. 64017-610. Teresina, PI, Brazil. E-mail: smithanny@live.com
} 


\section{Introduction}

The climacteric period has deserved greater attention in the field of public health, mainly due to the increase in the number of women over 50 years old and to how this period affects their lives. Climacteric is regarded as a period of transition between women's reproductive and non-reproductive phase, which begins around the age of 40 years old, in which about $75.0 \%$ of women develop intense symptoms as a result of progressive ovarian failure ${ }^{(1)}$. Climacteric is also defined as an endocrine phenomenon that is characterized by the depletion of ovarian follicles and hypoestrogenism, which last until the middle of 65 years old ${ }^{(2)}$.

The increase in the number of women is related to the demographic and epidemiological transition process that was accelerated in a big part of the planet. In developed countries $95.0 \%$ of women reach the menopause and $50.0 \%$ live more than 75 years. In Brazil, from 1980 to 2000, the proportion of elderly people who are more than 60 years old increased from $6.1 \%$ to $8.6 \%$, with an estimated number of $14.0 \%$ by 2025. The World Health Organization projects that by 2025 , the number of older people will increase between seven and eight times in several countries of Latin America, Africa and Asia.

In this sense, a greater concentration of professional efforts is necessary, especially for nurses and health managers to get ready for the attendance of this audience, so that climacteric women have a more qualified assistance, live longer, seek to have more quality of life according to their own possibilities and keep their mental and physical functions until next to the end of their lives.

So when considering the life expectancy of women around 77 years old, and that about a third of their lives will be in the climacteric period, and for being permeated by taboos and prejudice, this study is justified in order to contribute with the quality of care. And from the perspective of the climacteric period being a cultural and psychosocial phenomenon, it has different meanings, which suffer the influence of the historic moment and of the society in which the subjects are inserted, and that, besides being loaded with culturally established meanings, they change through the interference of subjects and get new meanings.

The study of social representations was developed by Serge Moscovici, in the 1950s, and it is the way individuals interpret the world in which they live, based on their life stories, beliefs, values and religion. This theory was used in this study for dealing with the subjectivity of the facts and assist in the analysis of the assistance provided by nurses to the women in climacteric ${ }^{(3)}$.

Then, one settled as the object of study the social representations of nurses about assistance to climacteric women in primary care. The knowledge of nurses about the climacteric is paramount to a more qualified and humanized assistance to women. In this sense, one has developed the following questions, which guide this study: what are the social representations developed by nurses from primary care about the assistance to women in the climacteric? What psychosocial aspects influence behaviors and practices related to the assistance to climacteric women?

In seeking to answer these questions about the health care to women in the climacteric period the following aim was built: to aprehend the social representations elaborated by nurses of the family health strategy concerning the assistance to women in the climacteric.

\section{Methods}

It is a qualitative study, in which one adopted as a theoretical-methodological path the theory of social representations, in its procedural approach ${ }^{(3)}$, since the representations we have from that period can interfere with the interactions, spontaneous communication and everyday practices. It was held in basic health units of a capital in the northeast of 
Brazil, which has 251 teams and $96.9 \%$ of coverage of the family health strategy.

The study included the participation of 28 nurses, who were selected based on the criteria of inclusion: being for at least five years on the team, time considered as long enough for nurses to have deep knowledge about the demands of the population assigned. For the selection of the participants, it was conducted a survey with the date of admissions from the base of the national register of health establishments of all nurses from a regional health board of the city, obtaining 48 nurses who were able to participate in the research. The sample definition was done through the saturation of the speeches, defining the suspension of inclusion of new participants when the data obtained started to present, in the researcher's evaluation, certain redundancy or repetition, not being considered as relevant to persist in the data collection. The variables age, sex, length of training, education, time of work in the strategy and time of performance in the current team were used to determine the profile of the participants.

For the data collection one used an interview guided by a script, which allowed the collection of socio-demographic data and an open question to encourage nurses to talk about the healthcare provided to climacteric women.

The data were collected in the basic health units, after the first interview for instrument testing. The interviews were carried out with prior appointment by telephone or in person, depending on the participants' availability and recorded in Mp4 after authorization. Then they were transcribed in full, for later reading and re-reading of the speeches.

The software ALCESTE [Análise Lexical de Coocorrências em Enunciados Simples de um Texto Lexical Analysis of Co-occurrence in Simple Statements of a Text] was used for the production and analysis of data, in its 4.7 version. It was used to perform analysis of textual data automatically in order to quantify a text and to extract the most significant structures. This software has contributed with the psychosocial language analysis through the statistical analysis of qualitative data that came from the verbalization of ideas, thoughts and texts of various types, which defines textual semantic classes ${ }^{(4)}$.

The nurses' speeches were prepared according to the guidance of using the software ALCESTE $2010^{(5)}$. Initially, the compound words or important expressions were identified, such as "age group", "physical activity", "family health strategy". Then, the textual material was formatted with lowercase and one added the underscore for compound words. The program identified the corpus at different initial context units. Each interview was considered a unit. The variables: gender, time of training, education, performance in the strategy and time of performance in the current team received a code, and each unit was identified by a code line preceded by asterisks, for the recognition of the program.

The corpus was subjected to an analytical treatment by ALCESTE, according to four stages (A, B, C, D), totaling 293 elementary context units (ECU), using $82 \%$ of the total and indicated, by means of descendent hierarchical classification, two classes.

Class 1 was composed of 98 units of elementary context, contributing with $33.5 \%$ for the study and class 2, consisting of 195 units, contributing with $66.5 \%$. From the full report provided by the program, the reading of the contents of the units was performed, for appointment and interpretation of the emerged classes. The classes presented bring the words in their reduced forms, with their respective frequencies and corresponding chi square $\left(x^{2}\right)$.

The study respected the formal requirements contained in the national and international regulatory standards for research involving human beings.

\section{Results}

The subjects are women, belonging to the age group from 50 to 59 years old $(46.4 \%)$, have 20 and more years of training (64.3\%), lato sensu postgraduate courses (92.8\%), ten years of experience 
in the team $(82.2 \%)$.

The description of the indicative classes of social representations elaborated by nurses about the assistance to climacteric women in primary care provided an understanding of the class contents, which arised after the analytical treatment by ALCESTE. These classes were named after several readings that took into account the meanings extracted from speeches and allowed the identification of the context of collective discourse that nurses experienced in their daily practice in relation to the object of study. In this sense, it was highlighted the class 1) which shows the cytology collection in the assistance to climacteric women, and the class 2) which refers to the actions of nurses in the assistance to climacteric women.

\section{Cytology collection in the assistance to climacteric women in primary health care}

The social representations seized in the words 'cytology, prevention, and examination results', associated with their full forms, describe the assistance to women in the climacteric period, and they are mainly focused on the conduction of the cytology or prevention and on the procedures according to the tests results. In this perspective, the social representations of assistance to women in the climacteric period are based on a hegemonic health care model. We make the collection, women come back for the result, we tell them about the negative result for malignancy, we also guide them about cytology, which does not identify inflammation, cytology prevents cervical cancer, so that's our assistance, to identify the problem and forward it. And, in general, the follow-up that we can give here are the collections of cytology, which are made according to the complaints, needs, period they wish to make it, when it is necessary to do so, so we end up making a consultation with the woman, who does the cytology examination, gets the result, makes the treatment, and if it is necessary we give orientations (ECU24).

Another representation seized refers to the verb 'guide'. It mentions the important role of nurses in the team, as educators regarding health promotion and diseases prevention, which is fundamental to the integration of women in the autonomy of their bodies. Here's the speech: We make the necessary referrals according to the result of the prevention exams, and during prevention, we also guide them about the importance of their monitoring, of making a mammogram, of having appointments with the doctor, the guidance in the office is done. We don't work based on this, but the orientation is given both in the nursing consultation and in the cytology collection. Guiding (ECU15).

According to ECU6 the activities carried out by nurses in the assistance to climacteric women take place mainly by spontaneous demand of women in the health services. The representation seized in this class refers to the word 'forwards'. The units allowed the inference of sociocognitivos content, due to referral to the doctor.

A fact that is crystallized in the constant referral to a doctor or specialist of the team: And then we forward them to a professional, in this case a gynecologist. And there they will really make the consultation, we will request the examinations, we will identify if it is really the climacteric period, giving the referrals needed both for the doctor of the family health strategy or guiding them to look for an expert, who is the gynecologist, I guide them to search for the general practitioner of the team and he in turn, according to the circumstances, forwards the woman to the gynecologist, if applicable (ECU6).

Another social representation that was seized is the difficulty of working in communities with low socioeconomic conditions and without infrastructure, where most people have the family health team as the only form to use health services, what makes these communities have a demand for curative actions. In communities characterized by high levels of violence, there is the difficulty to access these areas to conduct actions, and then the nurses reported that: Many patients are in this cycle of life. Cytology collections, record of needs in the medical charts and required referrals are made. We've already said that we work in two communities and those communities are very poor and violent and this leads us to develop precarious health promotion activities (ECU6).

In this class it was found out that nurses believe that the climacteric period is a condition that should be conducted by a medical professional, and that 
nurses should track the cervical cancer, dissociated from the whole consultation.

\section{Nurses' actions for the assistance of climacteric women}

The class 2 highlights the presence of sociocognitive content by exposing the participants about nurses' role in assistance to climacteric women, with information full of doubts, concerns and feelings of helplessness.

Nurses showed that the assistance to climacteric women in primary care does not meet the real needs of patients. The words 'really, stays, symptom' show that nurses believe that the assistance to women in the climacteric period is more focused on the symptoms women present: Depression, sadness and even the lack of energy in their daily activities. And it turns out that, for being an spontaneous action, the assistance ends up not being really targeted in the climacteric period, what is a failure of the health team, because the team ends up worrying only about the apparent injury (ECU21).

The apprehension of nurses' social representations about the assistance to women in the climacteric period, obtained through the participants' speeches, which represent day-to-day practices and behaviour, demonstrated that nurses consider climacteric as the phase of a woman's life that deserves the biggest attention: A woman in climacteric needs other care measures related to quality of life, I mean: to have a proper diet for her age. She is a woman who needs to pay attention if she has hypertension or not. And if she is making the prevention of hypertension, as well as diabetes because, whether she likes it or not, with age, women, like men, become more vulnerable, but we're talking about women, there are more risk factors to have hypertension and diabetes, both for any pathology that they have and for making prophylaxis of some other diseases, as in osteoporosis. So, I think it's a phase that women need attention, like any other, but in the climacteric period due to this vulnerability, women are more sensitive in this age group, more likely to have depression, more likely to develop certain diseases. So, I think that this is what counts. And it includes from the clinic to the physical activity. And we should have that look of expanded and integrated clinic and
I think that's all. Then you will see the climacteric, high blood pressure, diabetes, you will see leprosy, tuberculosis, you will see everything (ECU21).

The representation seized that was anchored to the feeling of powerlessness and inability to follow climacteric women demonstrates the knowledge of nurses in dealing with these women in this period. I am not very familiar with this theme and I don't feel ready to be working, I think it's still a little shy, I think we would need to rescue more. But I see that we don't have that look that they really deserve and we see that it is a phase when complaints are numerous, and unfortunately we do not have the knowledge (ECU10).

With the words 'have, work, climacteric', nurses recognize that it is part of their role to develop activities related to menopause, despite the lack of systematized actions: We are very interested in working with this issue of menopause, but it's like I'm telling you, the area is not very easy, this relationship has to be built. Saying that there is a policy, there is an active search for these women in the climacteric, the team still does not do it (ECU10).

In order to assist climacteric women in a more comprehensive and conclusive way, nurses raise the need for a reference centre or something similar, because women are often forwarded to experts who do not look at them regarding a completeness of care and women return to primary care professionals without having their troubles solved or minimized. I think they need to be very well received at health services. And we realize a deficiency in services to assist women, because we don't have any referral services to assist women in any age group, except women with cancer, we have a more formal referral service, sometimes she will be assisted by someone who focuses only on a certain thing. Oh! "I only perform surgeries" or "I only make examinations". They don't really try to understand this phase as a whole. And it is still very sad, but I think there is still time to reverse it. They deserve it, they need it (ECU18).

Nurses highlighted that the educational actions have a fundamental importance for women to become active in the process of menopause: And we know that this assistance in the climacteric is very important, that women are considered as abandoned. Even so, without guidance, without knowing, I don't know if you understand what I'm talking about. I feel 
that women are still a bit loose in these matters because they come to us, and they don't realize if they are actually in menopause (ECU20).

Nurses realize that the assistance to climacteric women is not held in its completeness: Listen, when a patient has signs and symptoms, presents hormonal change in tests then I try to talk to the medical team, because we don't have a systematized thing, such as: today we're going to attend climacteric women (ECU20).

In this class nurses recognize the need for a full assistance to women in the climacteric period, and the need to look for other ways to approach and to ensure the best quality service.

\section{Discussion}

The limitations of this study are related to the small number of subjects and the investigation in a single health unit. However, the results have the potential to disclose contexts of weaknesses perceived by nurses, transversalized by the influence of (un) knowledge about menopause and how to take care of women in this phase.

The social representation of nurses about the care developed with women in the climacteric period showed that the biomedical model remains dominant, with focus on health recovery actions, aimed at curing diseases, because health representations are still under construction, which will consider its broad concept ${ }^{(6)}$. In this perspective, the fragmented and reductionist approach of the type consultation/request of exams/ prescription, reinforces in women's imagination the perception of climacteric as a symbol of aging and existential weakening, increasing women's suffering.

Sometimes women's pain are investigated through tests, when in fact the diagnosis could be made looking in their eyes ${ }^{(7)}$. Despite the progress in the health sector in relation to the pursuit of full attention, in terms of assistance, fragmented actions are still reproduced in the traditional programs and campaigns without reflecting in the improvement of women's care ${ }^{(6)}$. Given this, nurses have performed nursing consultations similar to medical consultations, which values only the physical processes, such as the pathology and physiology of a disease ${ }^{(8)}$.

The constant referral of climacteric woman to a general practicioner or to a gynecologist demonstrates that nurses attribute the responsibility of climacteric assistance to these professionals. In this way, it can be noticed on nurses' speeches that the climacteric is a health problem that requires medical intervention ${ }^{(9)}$. With that, one can see that, despite the advances of public policies in the context of attention to climacteric women, there is still a delay in the implementation of strategies that effectively impact on the quality of life of these women. This seems to arise from the pressure that the hegemonic or biomedical model still carries on the population's health care. The rooting and reproduction of this culture in the practice of health care have generated positions consistent with this model, since no mind is free from the effects of previous constraints imposed on them by their representations, language and culture ${ }^{(3)}$.

Health actions must be adjusted according to the specificities of the territories and to people's everyday life to get an approximation of the social production of the community's health problems ${ }^{(10)}$. Health is considered by the community as the absence of pathology, so the population tends to look for health services, in most cases, when there is a disease. In this sense, the changes in the style of health care are not seen by individuals. Then, they continue to search for curative actions in the health services.

In this study, nurses reported having difficulties to assist women, but acknowledged the importance of assistance and expressed the desire to participate in their training, the lack of knowledge on the subject can be the cause $\mathrm{e}^{(11-12)}$, of not being systematically established in the work routine.

The assistance to climacteric women requires their active participation, so that these women acquire healthy eating habits, practice physical activity, adopt a new lifestyle seeking a better quality of life. According to common sense, making people have a healthy lifestyle is difficult and often frustrating, as if the 
motivation for the transformation was an unchanging state, associated with the idea that the professional has to be the holder of knowledge, power and content domain, often disregarding the knowledge of women and of the community in which they are inserted, and it establishes a hierarchical relationship of superiority, which makes it hard the adhesion to the activities recommended ${ }^{(13)}$.

Then, about the assistance to women in the climacteric period, one realizes that the actions are dependent on individual initiatives and on the sensitivity of each professional. Given this, the actions are often disjointed, disorganized and are not inserted in the daily lives of health professionals.

In this sense, including actions that promote the quality of life in this assistance is recommended ${ }^{(13-15)}$, in order to improve women's satisfaction in their family, love and social lives, in this perspective, a full usercentered care as a strategy for health care requires nurses to perceive these users in their multiple dimensions and rethink the work processes in order to achieve the effectiveness in a more humanized and full way.

In order to solve the difficulties, a permanent education is essential, since the lack of knowledge about menopause as a multifaceted phenomenon and the fact that the assistance to women who seek the services is not focused on its uniqueness make such assistance not effective. Thus, strategies to accomplish the process of health education for women are also a challenge for permanent education, because in the same way that there is an intense presence of the biomedical model in the population's health care, one still realizes the permanence of the banking model of education.

For the conduction of educational activities, nurses should have skills and techniques that allow women to talk about their wishes, questions and they should acquire information related to climacteric women, from physiological aspects of climacteric, its manifestations, the implications on women's lives, the complications and ways of coping as well as deconstruct myths and taboos, among others, respecting women's individuality, the cultural context where they are inserted, the prior knowledge they have about climacteric, their habits in relation to eating and their availability for self-care.

In addition, both nurses and users suffer influence of the globalization process, of the media and of pharmaceutical industries, through the construction of women's image based on values founded on beauty, youth and fertility. This influence has modified social values in relation to aspects of menopause because, if this influence is increasingly associating the climacteric period to a negative phase of women's lives, this will have as a consequence the transformation of the climacteric in a difficult period for women with the exacerbation of some symptoms. This makes women more vulnerable to medicalization over the acquisition of healthy lifestyle habits.

With the deployment of systematization of nursing care $^{(16-17)}$ and the use of integrative and complementary therapies and practices, climacteric women's assistance would make a quality leap, mainly in order to reduce the impacts generated in this process in which numerous changes occur. Given this, primary care nurses must have knowledge about menopause $^{(18)}$ and about the management of these women in order to prepare them to work actively in the climacteric and make them able to adapt to physical or psychological changes observed in this phase.

\section{Conclusion}

The social representations apprehended are: the cytology collection, the nursing consultation, educational guidelines are the main activities of nurses in the assistance to climacteric women. And that the care to climacteric women is the medical professional's responsibility, therefore climacteric is seen as a health problem that requires medical intervention. But we should also consider that it is a phase of life in which women deserve a differentiated attention, but do not 
feel prepared to promote this care in a full way, which creates feeling of powerlessness and inability to keep up with women in this phase.

Then, the activities carried out in the assistance to climacteric women are restricted to those women who search for the service spontaneously. Those who are accompanied in a systematic way, for being inserted in the groups of users suffering from chronic diseases receive care only in aspects related to the injury.

This way, training is critical in order to improve the quality of care, not only in the sense of the menopause itself, but in the breadth of this process that interferes so much with women's lives. This training should guide professionals about techniques and skills that can make them able to work with the subjectivity of climacteric women. Health professionals should use more interactive education techniques, in which they take on the role of facilitators and use integrative and complementary therapies, in order to expand their vision of the health/disease process and the global promotion of human care, especially with emphasis on self-care.

Based on these considerations, it is recommended that managers implement public policies on attention to climacteric women, give specific training and continuing education to health professionals who work with these patients, include integrative and complementary therapies or practices in their assistance, because this clientele may have more quality of life.

\section{Collaborations}

Silva SB and Nery IS contributed to the design, data collection, analysis, interpretation of data, article writing, intellectual review of the content and final approval of the version to be published. Carvalho AMC contributed with the article writing and with the final approval of the version to be published.

\section{References}

1. Santos RDS, Carvalho FGD, Lima TP, Viegas RL, Faria A, Suen VMM, et al. Perfil do estado de saúde de mulheres climatéricas. Medicina (Ribeirão Preto). 2012; 45(3):310-17.

2. Leite ES, Oliveira FB, Martins AKL, Ramalho KKA, Torquato JA. La perspectiva de las mujeres sobre la menopausia: conceptos y los impactos sobre la salud en atención primaria Perspectivas de mulheres sobre o climatério: conceitos e impactos sobre a saúde na Atenção Básica. Rev Pesq Cuid Fundam Online. 2012 [citado 2016 mar. 07]; 4(4):2942-52. Disponível em: http://www. seer.unirio.br/index.php/cuidadofundamental/ article/view/1850/pdf_636

3. Moscovici S. Representações sociais: investigações em psicologia social. Petrópolis: Vozes; 2010.

4. Soares C. Em torno do pensamento social e do senso comum. A aplicação da metodologia ALCESTE em contextos discursivos distintos. In: Moreira ASP, organizador. Perspectivas teóricometodológicas em representações sociais. João Pessoa: Editora Universitária; 2005. p 541-71.

5. Image. ALCESTE Windows. Análise de dados textuais. Toulose: Image; 2010.

6. Vidal CRPM, Miranda KCL, Pinheiro PNC, Rodrigues DP. Mulher climatérica: uma proposta de cuidado clínico de enfermagem baseada em ideias freireanas. Rev Bras Enferm. 2012; 65(4):680-4.

7. Rosa SD, Brançam GS. A intervenção grupal como recurso da Terapia Ocupacional: uma experiência com mulheres climatéricas. Cad Ter Ocup UFSCar. 2013; 21(2):423-8.

8. Gomes AMT, Oliveira DC. Autonomia profissional em um desenho atômico: representações sociais de enfermeiros. Rev Bras Enferm. 2010; 63(4):608-15.

9. Cavalcanti IF, Farias PN, Ithamar L, Silva VM, Lemos A. Função sexual e fatores associados à disfunção sexual em mulheres no climatério. Rev Bras Ginecol Obstet. 2014; 36(11):497-502. 
10. Junges JR, Barbiani R, Zoboli ELCP. Planejamento Estratégico como exigência ética para a equipe e a gestão local da Atenção Básica em Saúde. Interface. 2015; 19(53):265-74.

11. Beltramini ACS, Diez CAP, Camargo IO, Preto VA. Atuação do enfermeiro diante da importância da assistência à saúde da mulher no climatério. Rev Min Enferm. 2010; 14(2):166-74.

12. Silva CB, Busnello GF, Adamy EK, Zanotelli SS. The nurse actions regarding the importance of women healthcare in climacteric. J Enferm UFPE On line [Internet]. 2015 [cited 2016 Jan 25]; 9 (supl 1):312-8. Available from: http://www.revista. ufpe.br/revistaenfermagem/index.php/revista/ article/viewArticle/5374

13. Cavalcanti AM, Oliveira ACL, organizadores. Autocuidado apoiado: Manual do profissional de saúde. Curitiba: Secretaria Municipal de Saúde; 2012.

14. Fonseca TC, Giron MN, Bernardinelli LMM, Penna LHG. Quality of life on climacteric nursing professionals. Rev Rene. 2014; 15(2):214-23.
15. Oliveira PM, Portela RA, Nascimento WG. Quality of life during the climacteric: an evaluation conducted with the users of a UBSF in the city of Campina Grande-PB. Nursing. 2011; 14(160):5016.

16. Santos FOF, Montezeli JH, Peres AM. Autonomia profissional e sistematização da assistência de enfermagem: percepção de enfermeiros. Rev Min Enferm. 2012; 16(2):251-7.

17. Sousa JL, Zveiter M, Almeida VLM, Menezes HF, Mara G, Alves R. Educação em saúde como ferramenta à mulher no climatério: subsídios para o cuidado de enfermagem. Rev Pesq Cuid Fundam Online. 2011 [citado 2016 mar. 07]; 3(4):2616-22. Disponível em: http://www.seer.unirio.br/index. php/cuidadofundamental/article/view/1485/ pdf_471

18. Silva EM, Costa AF, Leite ES, Sobreira MVS. Climacteric according to the perception of women of a family health unit. Nursing. 2012; 14(165):7984. 